\title{
Comparison of the Inhibitory Effects of Famotidine and Cimetidine on Hepatic Oxi- dative Metabolism of Cortisol in Humans
}

\author{
Kunihiko MORITA* Hiroki KONISHI* Takeshi ONO* \\ and Harumi SHIMAKAWA*
}

(Received on Dec. 19, 1986)

* Hospital Pharmacy, Shiga University of Medical Science, Tsukinowa-cho, Seta, Ohtsu 520-21, Japan

The inhibitory effect of famotidine, a new $\mathrm{H}_{2}$-receptor antagonist, on hepatic oxidative metabolism of cortisol in six healthy volunteers was compared with that of cimetidine by monitoring the change in urinary $6 \beta$-hydroxycortisol $(6 \beta$-OHF), an oxidative metabolite of cortisol. The ratio of $6 \beta$-OHF to 17 -hydroxycorticosteroids (17-OHCS) in urine was measured before, during, and after treatment with famotidine and cimetidine for 3 days in a cross-over study. The ratio was decreased by $25 \%-35 \%$ of the original level after 1-3 days of oral treatment with cimetidine ( $800 \mathrm{mg}$, b. i. d.). The reduction vanished within 2 days after the last dose of cimetidine. The ratio was not significantly changed during oral treatment with famotidine $(40 \mathrm{mg}$, b. i. d.). These findings indicate that famotidine, in contrast to cimetidine, does not affect the hepatic oxidative metabolism of cortisol in man, and it is suggested that famotidine does not affect the hepatic drug-metabolizing capacity in humans.

Key words : famotidine, cimetidine, $\mathrm{H}_{2}$-receptor antangonist, $6 \beta$-hydroxycortisol, enzyme inhibition

\section{Introduction}

Cimetidine, a histamine $\mathrm{H}_{2}$-receptor antagonist widely used for the treatment of peptic ulcer, has

* 滋賀医科大学医学部附属病院薬剤部 画520-21 滋賀県大津市瀬田月輪町 been shown to inhibit the hepatic elimination of a number of drugs coadministred. ${ }^{1-4)}$ A number of studies have demonstrated that this inhibitory action of cimetidine is based on its high affinity for cytochrome $\mathrm{P}-450$ in hepatic microsomes arising from imidazole and cyano groups. ${ }^{5-7)}$ Ranitidine, an $\mathrm{H}_{2}$-receptor antagonist developed 


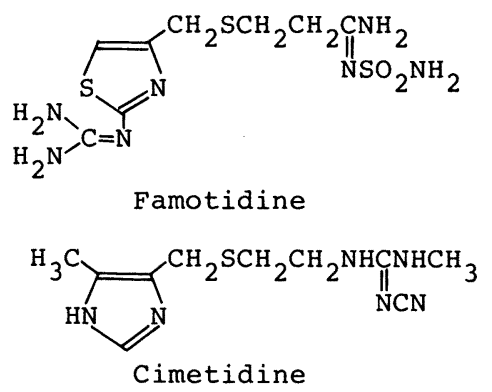

Fig. 1 Chemical structures of $\mathrm{H}_{2}$-receptor antagonists tested.

subsequently, has a furan ring structure and does not affect on oxidative drug-metabolizing enzyme activity in hepatic microsomes in vitro or in vivo. ${ }^{5-9)}$

Famotidine, a new $\mathrm{H}_{2}$-receptor antagonist containing thiazole ring structure (Fig. 1), has been reported to be clinically useful, since it exhibits inhibitory action of stimulated gastric acid secretion at least 20 times more potent than that of cimetidine. ${ }^{10)}$

On the other hand, it is well known that cytochrome $\mathrm{P}-450$ in the hepatic microsomes mediates oxidation of various steroid hormones such as testosterone and cortisol. Previously, we reported that cimetidine, but not ranitidine and famotidine, inhibits testosterone hydroxylase activities in mouse hepatic microsomes in vitro. ${ }^{7)}$ These findings suggest that cimetidine, in contrast to ranitidine and famotidine, inhibits the oxidative metabolism of endogenous steroid such as testosterone as well as xenobiotics.

In this study, we compared the effect of famotidine on the oxidative metabolism of cortisol in man with that of cimetidine, and assessed the inhibitory potency of famotidine on hepatic drug-metabolizing capacity in man.

\section{Subjects and Methods}

Six normal volunteers, 1 female and 5 male hospital pharmacists, aged 24 to 35 years old (mean 28), participated in the study. All subjects had normal hepatic and renal function. They were taking no medications.

All subjects received, on separate occasions, the oral dose of both famotidine (Gaster ${ }^{\circledR}, 40 \mathrm{mg}$ b. i. d.) and cimetidine ( Tagamet ${ }^{\circledR}, 800 \mathrm{mg}$ b. i. d.) for 3 days. Successive treatment was given two weeks after the previous drug treatment. On Day 0 (just before treatment) and Day 1,2,3, 4, 5 and 7, random urine samples were taken for the evaluation of the oxidative metabolism of cortisol. Urine samples were stored frozen at $-20^{\circ} \mathrm{C}$ until assay.

Oxidative metabolism of cortisol in the subjects was evaluated by the ratio of $6 \beta$-hydroxycortisol $(6 \beta-\mathrm{OHF})$ to 17 -hydroxycorticosteroids $(17-\mathrm{OHCS})$ in urine. Urinary $6 \beta-\mathrm{OHF}$ was determined by the method described in detail previously ${ }^{11}$ and urinary 17-OHCS was determined by the method of Nishikaze et al. ${ }^{12)}$ which is a modification of the procedure of Silber and Porter. ${ }^{13)}$

The ratio of $6 \beta$-OHF to $17-\mathrm{OHCS}$ in urine on Day 0 in each subject were corrected as the $100 \%$ and stastical significance was evaluated using a paired t-test.

\section{Results}

Figure 2 shows the change in the ratio of $6 \beta$-OHF to $17-\mathrm{OHCS}$ in urine obtained from the six subjects, before, during and after treatment with famotidine ( $40 \mathrm{mg}$, b.i.d.) or cimetidine $(800$ $\mathrm{mg}$, b. i. d.) for 3 days. As regards cimetidine, the ratio began to decrease on Day 1 and to reach about $65 \%$ of the original level on Day 3. After the discontinuation of the treatment with cimetidine, the ratio rapidly returned to its original level within 2 days after the last dose of cimetidine. On the other hand, famotidine had no significant 


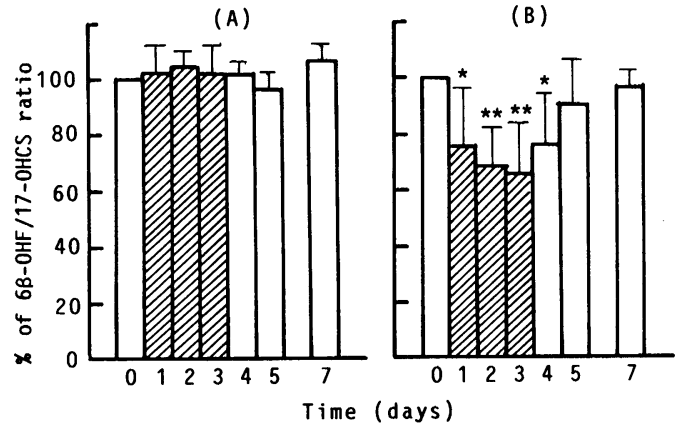

Fig. 2 Changes in the ratio of $6 \beta-O H F$ to $17-$ OHCS in urine obtained from 6 healthy volunteers before, during, and after 3 days of famotidine $(40$ $\mathrm{mg}$, b.i.d.) (A) and cimetidine ( 800 mg, b.i.d.) (B) treatment. The amounts of $6 \beta-\mathrm{OHF}$ and 17-OHCS in random urine obtained from the subjects on Day 0 (mean \pm S.D.) were $0.397 \pm 0.217 \mu \mathrm{g} / \mathrm{ml}$ and $9.86 \pm$ $3.38 \mu \mathrm{g} / \mathrm{ml}$, respectively. In individuals, the initial ratio ranged from 0.029 to 0.049 . The ordinate shows the percentage to the ratio on Day 0 in each subject. Each column represents the mean \pm S.D. Shaded areas indicate the periods during administration. * Significantly different from Day $0(\mathrm{P}<0.05)$. ${ }^{* *}$ Significantly different from Day $0(\mathrm{P}<0.01)$.

effect on the ratio.

\section{Discussion}

The results indicate that famotidine, in contrast to cimetidine, does not affect the oxidative metabolism of cortisol in man. The ratio of $6 \beta-$ OHF to $17-\mathrm{OHCS}$ in urine was decreased by 25 , 30 and $35 \%$ of the original level after 1,2 and 3 days of the treatment with cimetidine $800 \mathrm{mg} /$ day, respectively. The rate of reduction (25-35\%) was in accord with the data obtained by Feely et al. ${ }^{14)}$ using $300 \mathrm{mg} /$ day cimetidine for 7 days and by Goto et al. ${ }^{15)}$ using 400-800 mg/day cimetidine for 1-14 days. Although the inhibitory mechanism of cimetidine on the activity of the enzyme responsible for the formation of $6 \beta$-OHF from cortisol in human liver is not clear, the mode of the inhibition might have been of competitive type, since cimetidine inhibits the hepatic elimination of a number of drugs by competitive binding to cytochrome $\mathrm{P}-450 .{ }^{16.17)}$ Our findings suggest that cimetidine, but not famotidine, inhibits the hepatic oxidative metabolism of endogenous steroids in man as well as that of testosterone in mouse hepatic microsomes. ${ }^{7}$ In this study, the therapeutic doses of famotidine ( 40 $\mathrm{mg} /$ day) and cimetidine ( $800 \mathrm{mg} /$ day) used in the treatment of gastro-intestinal ulcer disease were selected. The concentrations of famotidine and cimetidine in the systemic circulation typically reach peak values in the 0.3-0.6 $\mu \mathrm{M}^{18)}$ and the $4-8.4 \mu \mathrm{M}^{19,20)}$ range, respectively, some $2 \mathrm{hr}$ after each oral therapeutic dose. Needless to say, the concentrations of both drugs in hepatic endoplasmic reticulum might differ. Considering that the values of inhibition constants of famotidine on testosterone $6 \beta^{-}, 7 \alpha$ - and $16 \alpha$-hydroxylase activities in mouse hepatic microsomes were 2. 3-10-fold larger than that of cimetidine ${ }^{7}$ and the results obtained here, it is unlikely that famotidine inhibits the oxidative metabolism of endogenous steroids in man at the therapeutic dosage.

On the other hand, measurement of the ratio of $6 \beta$-OHF to $17-\mathrm{OHCS}$ in urine is useful as a noninvasive method for evaluating the change in human hepatic oxidative drug-metabolizing capacity such as enzyme induction ${ }^{21-24)}$ and inhibition, ${ }^{14,15)}$ because $6 \beta$-OHF is a polar metabolite formed by the oxidative metabolism of cortisol by hepatic microsomes. A significant correlation has been found between the urinary excretion of $6 \beta$-OHF and total body clearance of antipyrine, which is useful as an in vivo param- 
eter of hepatic drug metabolism. ${ }^{23)}$ Actually, the inhibitory effect of cimetidine documented in the present study confirmed the findings in a study of antipyrine steady state kinetics in man by Teunissen et al ${ }^{25)}$; that is, antipyrine metabolism was reduced by about $30 \%$ during treatment with $400 \mathrm{mg}$ of cimetidine and the inhibition disappeared within $48 \mathrm{hr}$ after cessation of treatment. Consequently, the present result is suggested that famotidine, in contrast to cimetidine, has no effect on the oxidative metabolism of xenobiotics in man. Recently, famotidine was found not to impair the clearance of diazepam and procainamide in $\operatorname{man}^{26)}$

In conclusion, it is suggested that famotidine should contribute to safer drug treatment than cimetidine, since it does not affect the oxidative metabolism of endogenous steroid and xenobiotics.

We are grateful to the volunteers for their participation.

\section{References}

1) Flind, A. C. : Cimetidine and oral anticoagulants. Br. Med. J., 2: 1367 (1978).

2) Serlin, M. J., Mossman, C., Sibeon, R. G. et al. : Cimetidine: Interaction with oral anticoagulants in man. Lancet, 2 : 317-319 (1979).

3) Klotz, U. and Reimann, I. : Delayed clearance of diazepam due to cimetidine. N. Engl. J. Med., 302 : 1012-1014 (1980).

4) Desmond, P. V., Patwardhan, R. V., Schenker, $S$. et al. : Cimetidine impairs elimination of chlordiazepoxide (Librium) in man. Ann. Intern. Med., 93 : 266-268 (1980).

5) Knodell, R. G., Holtzman, J. L., Crankshaw, D. L. et al. : Drug metabolism by rat and human hepatic microsomes in response to interaction with $\mathrm{H}_{2}$-receptor antagonists. Gastroenterology, 82: 84-88 (1982).

6) Rendic, S., Kajfez, F. and Ruf, H.-H. : Characterization of cimetidine, ranitidine, and related structures interaction with cytochrome P-450.
Drug Metab. Dispos., 11:137-142 (1984).

7) Morita, K., Ono, T., Shimakawa, H. et al. : The effects of $\mathrm{H}_{2}$-receptor antagonists and imidazole on testosterone hydroxylations in mouse liver microsomes. Chem. Pharm. Bull., 32 : 4043-4048 (1984).

8) Speeg, K. V., Jr., Patwardhan, R. V., Avant, G. $R$. et al. : Inhibition of microsomal drug metab. olism by histamine $\mathrm{H}_{2}$-receptor antagonists studied in vivo and in vitro in rodents. Gastroenterology, 82:89-96 (1982).

9) Hoensch, H. P., Hutzel, H., Kirch, W. et al. : Isolation of human hepatic microsomes and their inhibition by cimetidine and ranitidine. Eur. J. Clin. Pharmacol., 29 : 199-206 (1985).

10) Miwa, M., Tani, N. and Miwa, T. : Inhibition of gastric secretion by a new $\mathrm{H}_{2}$-antagonist, YM-11170 in healthy subjects. Int. J. Clin. Pharmacol. Ther. Toxicol., 22 : 214-217(1984).

11) Ono, T., Tanida, K., Shibata, H. et al. : Highperformance liquid chromatographic detemination of $6 \beta$-hydroxycortisol in urine. Chem. Pharm. Bull., 34 : 2522-2527 (1986).

12) Nishikaze, O. and Furuya, E. : A new method for the determination of 17-OHCS (PorterSilber chromogen) in urine. I. the effect of sodium sulfate on the $\beta$-glucuronidase catalyzed reduction. Rinshobyori, $17: 634-638$ (1969). (in Japanese)

13) Silber, R. H. and Porter, C. C. : The determination of 17, 21-dehydroxy-20-ketosteroids in urine and plasma. J. Biol. Chem., $210: 923-$ 932 (1954).

14) Feely, J., Robertson, D., Island, D. P. et al. : Cimetidine alters plasma catecholamine levels and cortisol and aldosterone excretion. N. Engl. J. Med., $306: 1054$ (1982).

15) Goto, M., Ohnishi, C., Nakajima, S. et al. : Effects of cimetidine and ranitidine on hepatic monooxigenase activity in humans. Jpn. J. Clin. Pharmacol. Ther., $14: 605-611$ (1983).

16) Klotz, U. and Reimann, I. : Drug interactions through binding to cytochrome P-450: The experience with $\mathrm{H}_{2}$-receptor blocking agents. Pharm. Res., 2 : 59-62 (1984).

17) Sedman, A. J. : Cimetidine-drug interactions. Am. J. Med., $76:$ 109-114 (1984).

18) Kawai, R., Yamada, S., Kawamura, S. et al. : Metabolic fate of famotidine (YM-11170), a new potent $\mathrm{H}_{2}$-receptor antagonist (2) 
Absorption and excretion in dogs and humans. Oyo Yakuri, $27: 73-77$ (1984). (in Japanese)

19) Redolfi, E., Borgogelli, E. and Lodola, E. : Blood level of cimetidine in relation to age. Eur. J. Clin. Pharmacol., 15:257-261 (1979).

20) Bodemar, G., Norlander, B., Fransson, L. et al. : The absorption of cimetidine before and during maintenance treatment with cimetidine and the influence of a meal on the absorption of cimetidine-studies in patients with peptic ulcer disease. Br. J. Clin. Pharmacol., 7 : 23-31 (1979).

21) Conney, A. H. : Pharmacological implications of microsomal enzyme induction. Pharmacol. Revs., 19:317-366 (1967).

22) Kuntzman, R., Jacobson, M., Levin, W. et al. : Stimulatory effect of $\mathrm{N}$-phenylbarbital (phetarbital) on cortisol hydroxylation in man. Biochem. Pharmacol., 17:565-571 (1968).

23) Ohnhaus, E. E. and Park, B. K. : Measurement of urinary $6 \beta$-hydroxycortisol excretion as an in vivo parameter in the clinical assessment of the microsomal enzyme-inducing capacity of antipyrine, phenobarbitone and rifampicin. Eur. J. Clin. Pharmacol., $15:$ 139-145 (1979).

24) Morita, K., Shibata, H., Ono, T. et al. : Inducing effect of feprazone on hepatic drug. metabolizing enzymes in man. Eur. J. Clin. Pharmacol., 31 : 117-118 (1986).

25) Teunissen, M. W. E., Kleinbloesem, C. H., de Leede, L. G. J. et al. : Influence of cimetidine on steady state concentration and metabolite formation from antipyrine infused with a rectal osmotic mini pump. Eur. J. Clin. Pharmacol., 28:681-694 (1985).

26) Klotz, U., Arvela, P. and Rosenkranz, B. : Famotidine, a new $\mathrm{H}_{2}$-receptor antagonist, does not affect hepatic elimination of diazepam or tubler secretion of procainamide. Eur. J. Clin. Pharmacol., $28: 671-675$ (1985). 